Nejčastější prǐččiny stomatodynií našich pacientů

\author{
(Pưvodní práce - retrospektivní studie)
}

\title{
Burning Mouth Syndrome - The Most Common Causes of Our Patients
}

\author{
(Original Article - Retrospective Study)
}

\author{
Kaprálová S. \\ Klinika zubního lékařství LF UP a FN, Olomouc
}

\section{SOUHRN}

Dutina ústní, včetně sliznice rtů a retní červeně, je prostředí denně vystavované řadě látek, jež mohou mít iritační charakter a zpo̊sobovat tak řadu nepříjemných vjemů, které shrnujeme pod pojem dynie; v zahraniční literatuře se použivá název burning mouth syndrome (BMS). Kromě lokálních faktorů mohou hrát roli i celkové vlivy, eventuálně jejich kombinace. $Z$ hlediska terapie posuzujeme stomatodynie v užším slova smyslu, kdy nelze určit žádný $z$ uvedených faktorů, nebo stomatodynie v širším slova smyslu, kde při komplexním vyšetření můžeme vyvolávající faktor objasnit. Mezi lokální vyvolávající faktory patří zejména alergie na dentální materiály, galvanické dráždění, změny v mikrobiální flóře dutiny ústní, suchost úst podmíněná předchozími faktory anebo jako reakce na celkovou medikaci. Na vzniku dynií se tady podílejí celkový zdravotní stav pacienta, již zmiňované léky, hormonální a metabolické poruchy, neuropatie, angiopatie, radioterapie a chemoterapie. Cílem naší studie bylo nalézt některé $z$ uvedených př́ičin a zbavit tak pacienta strádání, které často může vést ke kancerofobiím značně omezujícím psychický komfort pacienta. Ve spolupráci s Kožní klinikou LF UP a FN v Olomouci jsme vyhledávali možné alergie na dentální materiály a na našem pracovišti jsme potom, na základě dalších vyšetření, monitorovali další etiopatogenetické faktory stomatodynií.

Klíčová slova: stomatodynie - burning mouth syndrome - alergie na dentální materiály

\section{SUMMARY}

Oral cavity, including lips and labial mucosa in red, constitutes the environment that is daily exposed to many substances that may have an irritative nature and cause many unpleasant sensations. This state is termed as a "dyny", in the foreign literature, a term Burning Mouth Syndrome (BMS) is used in addition to local factors may play a role in the overall effects, possibly combination of both. Stomatodynia divided into stomatodynia in the strict sense, it is not possible to identify any of these factors or stomatodynia in a broader sense, where a comprehensive examination of the precipitating factors can explain. Among the local factors evoking oral cavity irritation, we include allergies to dental materials, galvanic stimulation, changes in microbial flora of the mouth, dry mouth caused by above-mentioned factors and/or reaction to used medication. Thus, the emergence of dyny is governed by the overall health of the patient, the above-mentioned drugs, hormonal and metabolic disorders, neuropathy, angiopathy, radiotherapy and chemotherapy. The aim of our study was to find some of these above-mentioned causes, mainly of a local character, and to relieve the patient's suffering, which can often lead to cancerophobia and often to a substantial reduction of psychological comfort of the patient. In collaboration with the Dermatology Clinic, University Hospital in Olomouc, we searched for possible allergies to dental materials utilizing patch tests, we then monitored other etiopathogenetic factors of stomadynia evaluating detailed examinations.

Key words: stomatodynia - Burning Mouth Syndrome - allergies to dental materials 


\section{ÚVOD}

Dutina ústní, včetně sliznice rtů a retní červeně, je prostředí, které je během života permanentně vystavováno velkému množství látek $\mathrm{s}$ iritačním či senzibilizačním potenciálem. Při běžném stomatologickém ošetření může na sliznici ústní dutiny působit několik kovových prvků ve formě sloučenin - solí, dále syntetické akryláty, topická léčiva, antiseptika a jiné stomatologické prostředky. Rovněž i sám pacient může používáním řady látek (kosmetika, orální léčebné př́ípravky apod.) ovlivňovat stav sliznice úst. Sliznice je tak opakovaně vystavována nebo trvale exponována širokému spektru látek. Výsledkem tohoto působení mohou být potíže, které obvykle označujeme jako stomatodynie.

Příčiny stomatodynií můžeme tedy rozdělit na lokální nebo celkové. Často se jedná o kombinace obojího, a proto musíme dynie posuzovat jako komplexní problém. Většinou se jedná o pacienty anxiózní, neklidné, dosti často pod vlivem stresu.

Mezi nejčastější potíže pacientů patří pocity pálení v ústech, hrdle, na rtech a jazyku, pocity popálení, opaření, otoku sliznic, rtů a jazyka, sucho v ústech a s tím spojené poruchy vnímání chuti, pachuti $[10,16,23,26]$.

Nejvíce postiženou skupinou lidí je populace ve věku nad 60 let. Zde lze přihlédnout k obecnému stárnutí organismu se vznikem senilní atrofie orgánů, kdy sliznice ústní dutiny jsou citlivější a náchylnější pro vznik dalších chorob [23]. Mezi postiženými jsou často ženy, hovoříme o takzvaném postmenopauzálním syndromu. Zastoupení žen a mužů se pohybuje v poměru 3:1 až 16:1 [9, 10].

Rozlišujeme dva typy dynií. Ve většině případů se jedná o potíže bez objektivního identifikovatelného nálezu na sliznici ústní dutiny, potom hovoříme o stomatodynii v užším slova smyslu, nebo můžeme nalézt určité změny celkového zdravotního stavu nebo změny lokálního charakteru, potom hovoříme o stomatodynii v širším slova smyslu.

Mezi nejčastější lokální přičiny patří poruchy salivace, bakteriální či mykotická infekce, stomatitidy, přitomnost nadprahových hodnot galvanických proudů, zlozvyky, vrozené anomálie jazyka, dráždění destruovaným chrupem či nevyhovujícími snímacími náhradami, projevy kontaktní alergie (dentální materiály, hygienické prostředky, kosmetika). $Z$ celkových příčin jsou to nejčastěji metabolické a hormonální poruchy, onemocnění gastrointestinálního traktu, komplikace protinádorové terapie, následky celkové medikace, trauma či operace v oblasti obličeje, poruchy inervace, ateroskleróza. Svưj podíl nese také kouření a stres [2, 10, 26, 27, 28].

V posledních letech přibývá osob, u kterých se vyskytují alergické reakce. Důvodem je př́liv nových dentálních materiálů, u nás doposud nepouživaných. Nejčastěji je postižena sliznice dutiny ústní, zejména bukální, palatinální a části jazyka přiléhající na dané materiály a dále rovněž rty $\mathrm{v}$ podobě cheilitid. Klinickým projevem je kontaktní alergický ekzém [1, 6, 13]. Za tuto reakci odpovídá IV. typ alergické reakce, takzvaný pozdní nebo též buněčný.

Alergické projevy se však mohou prezentovat také formou celkových potíží, jako je únava, bolesti hlavy, nadměrné pocení, nevolnost.

V dutině ústní se můžeme setkat i s I. typem alergické reakce - anafylaktickým (časným, atopickým). Jedná se o reakci s rychlým nástupem a rozvojem po kontaktu s alergenem (látky bílkovinné povahy, hapteny). Většinou se jedná o reakci na léky - anestetika, projevem bývají lékové reakce, Quinckeho edém.

Mezi nejčastější alergeny patří amalgám, dentální slitiny, plasty, otiskovací hmoty. Stále častěji bývá také diskutována alergie na latex. Velkou skupinou kontaktantů jsou esenciální oleje, které jsou součástí prostředků na čištění zubů; nacházíme je v zubních pastách, ústních vodách a v dentálních cementových tekutinách. Využivá se jejich antiseptických a mírných analgetických účinků a aromatických vlastností k zamaskování nepř́ijemných chutí (např. skořicový a anýzový olej) [3].

Častým zdrojem nepř́ijemných pocitů v ústní dutině je porušený ekosystém tohoto prostředí. V ústech nacházíme smíšenou mikrobiální flóru skládající se $z$ bakterií, virů, kvasinek, prvoků, dále jsou zastoupeny chlamydie a mykoplazmata. Zjištujeme jak kmeny anaerobní, tak i aerobní. Některé mikroorganismy jsou v dutině ústní přitomny pravidelně, jiné se vyskytují jen př́ležitostně. Mikrobiální flóra je nesmírně pestrá a na její 
složení má vliv celá řada faktorů. Vztahy mezi mikrobiálním ekosystémem dutiny ústní a lidským organismem jsou po většinu doby jejich trvání oboustranně výhodné [20]. Vlivem řady lokálních i celkových faktorů může docházet ke změně složení mikrobiálního osídlení ústní dutiny.

Kvalitativní i kvantitativní změna ve složení orální mikroflóry vede $\mathrm{k}$ řadě problémů, které lze shrnout pod termín stomatodynie, neboli pálivý syndrom dutiny ústní (burning mouth syndrome). V posledních letech se setkáváme s narůstající incidencí tohoto onemocnění. Častou př́íčinou bývají kandidy, které je nutno považovat za podmíněné patogeny. Zejména Candida albicans má schopnost adherence na slizniční receptory a může na sliznici vyvolat orální kandidózu.

Orální kandidóza je poměrně častou oportunní infekcí ústní sliznice, vznikající u dočasně nebo trvale disponovaných osob při lokálním či celkovém narušení jejich obranyschopnosti [12]. Počet těchto infekcí u populace narůstá a nabývá v lékařské vědě na významu [20]. Klinický obraz slizničního postižení může být typický, tj. provázený tvorbou bělavých pseudomembrán, lpících na zarudlé sliznici, nebo atypický, manifestující se pouze erytémem ústní sliznice jako takzvaná bezpovlaková erytematózní kandidóza (akutní i chronická, tzv. atrofická forma), projevující se palčivostí ústní sliznice a suchostí [12, 18, 22].

$\mathrm{S}$ přemnožením kandid v dutině ústní (DÚ) dosti často souvisí hyposialie čili nedostatečné déletrvající množství slin $\mathrm{v}$ ústech. $Z$ toho plynou jak subjektivní potíže pacienta, tak objektivní nález na sliznicích i na tvrdých zubních tkáních [19].

V ordinaci můžeme celkem snadno provést sialometrický test, hodnotící salivaci kvantitativně, nejběžněji tzv. Škachovu zkoušku [21]. Tento test objektivně stanoví, zda pacient trpí nedostatečnou salivací, či se jedná pouze o subjektivní pocit bez klinického podkladu.

Xerostomie může negativně působit na kvalitu života, ovlivňuje stravovací návyky, nutriční stav, hlas, chut, toleranci k zubním náhradám a zvyšuje náchylnost k zubnímu kazu. Poruchy salivace představují pestrou medicínskou problematiku, k jejíž léčbě je třeba spolupráce více lékařských oborů. Většina nemocných však první ošetření vyhledá u zubního lékaře.

Poměrně častým nálezem na sliznici dutiny ústní jsou kožní onemocnění, zejména je to orální forma lichen planus (OLP), který může postihovat kromě sliznice také připojenou gingivu v podobě deskvamativní gingivitidy. Etiopatogeneze není zcela jasná, ale předpokládá se imunopatologická reakce, vyvolaná různými etiologickými faktory. Klinickým obrazem se řadí k syndromu bílé plochy [14]. Diagnostika orálních lichenoidních změn je založena na detailní anamnéze, klinickém vyšetření a histopatologickém nálezu. Je popsána řada klinických forem. Subjektivně pacienti udávají pocit drsného povrchu, pálení, štípání až bolestivosti.

Jak již bylo řečeno úvodem, příčin pálivého syndromu mưže být několik a naším cílem bylo pokusit se najít důvod onemocnění, léčit ho nebo alespoň zmírnit potíže našich pacientů. $V$ př́ipadě alergických reakcí potom zabránit dalšímu kontaktu s alergenem a pacienta tak nevystavovat další fyzické a psychické újmě.

\section{METODIKA}

V letech 2006-2007 se z pacientů, kteří se dostavili na naše oddělení parodontologie s problémy, jevícími se jako pálivý syndrom, vytvořil soubor, který byl zařazen do grantového projektu ve spolupráci s Kožní klinikou LF UP a FN Olomouc.

U všech pacientů jsme podrobně odebrali anamnézu, která byla složena $z$ následujících částí:

a) osobní anamnéza - veškeré údaje o zdravotním stavu pacienta, léky, jež užívá či užíval, rodinná zátěž;

b) alergická anamnéza - potraviny, pyly, prach, léky, kovy atd.;

c) sociální anamnéza - současná i minulá;

d) kouření, alkohol, zlozvyky;

e) současné subjektivní potíže, délka trvání, dosavadní léčba, podrobně celý průběh potíží, eventuálně návaznost na nějakou událost. 
Dalším vyšetřením, které následovalo, byl vlastní klinický objektivní nález na sliznicích, žurnální záznam chrupu. Pokud pacient měl alespoň částečně zachovaný sanovaný chrup, provedli jsme měření galvanických proudů (měření provádíme mezi různými kovy, ale i mezi pracemi $z$ téhož materiálu - možnost použití např. jiných typů amalgámů). Při další kontrole byl proveden stěr $z$ DÚ na mikrobiologické vyšetření, pacient přichází na lačno, chrup si nečistí a ničím nevyplachuje. Další kontrolu jsme naplánovali většinou za tři týdny, kdy pacienti absolvovali Škachův test (pokud udávali suchost DÚ), dále byli vybraní pacienti s klinickým nálezem bílé plochy podrobeni diagnostické biopsii. Současně jsme přihlíželi $\mathrm{k}$ výsledkưm mikrobiologického vyšetření a zavedli jsme adekvátní léčbu. Vyšetření bylo doplněno panoramatickým rentgenovým snímkem. Pacient byl poté odeslán na Kožní kliniku k provedení epikutánních testů. Po jejich odečtení následovala léčba, která spočívala:

a) v př́ípadě pozitivních epikutánních testů či pozitivních hodnot galvanismu v odstranění nevyhovujících konzervačních a protetických prací a jejich náhradě $z$ odpovídajících inertních materiálů;

b) v přeléčení mikrobiální či kvasinkové infekce a provedení kontrolního stěru;

c) v podpůrné terapii - vitaminy, potravinové doplňky, bylinné čaje;

d) ve spolupráci s jinými obory, např. s neurologií, internou, ORL a dalšími.

Podle našich zkušeností a výsledkủ daných vyšetření bylo často nutné léčení na více úrovních, pacienti byli podrobeni postupně několika léčebným procedurám. Po dokončení terapie vždy sledujeme její úspěšnost či neúspěšnost v dalších kontrolách pacienta na našem oddělení. Pokud dojde k úplnému odeznění potíží a pacient tudíž nepotřebuje dále naši péči, poučíme ho a odešleme zpět do spádové oblasti. V př́ípadě jakýchkoliv potíží nás může kdykoli kontaktovat, dokumentace zůstává archivována. Přeje-li si pacient chodit k nám dále na kontroly, dohodneme se obvykle na půlročních nebo ročních intervalech. Jiná situace nastává u pacientů s přetrvávajícími potížemi, kdy je u nás nutná dispenzarizace a častější kontroly. Jejich četnost je individuální a závisí na daném zdravotním stavu každého jednotlivce.

\section{VÝSLEDKY}

Soubor tvořilo 128 jedinců, $z$ toho 105 (82 \%) žen a 23 (18 \%) mužů, poměr žen a mužů je přibližně 4,6:1, čili poměrové zastoupení odpovídá údajům uváděným v literatuře. Průměrný věk celé skupiny byl 59,68 let, přičemž ženy dosahovaly průměrného věku 60,13 a muži 57,65 roků. Nejmladšímu pacientovi bylo 21 a nejstaršímu 84 let, v obou př́ipadech se jednalo o ženy. Průměrná délka trvání potíží byla 15,8 měsíců, nejkratší dobu uvedl muž - jeden týden. Pacienty jsme postupně podrobili jednotlivým vyšetřením, jak je popsáno v metodice.

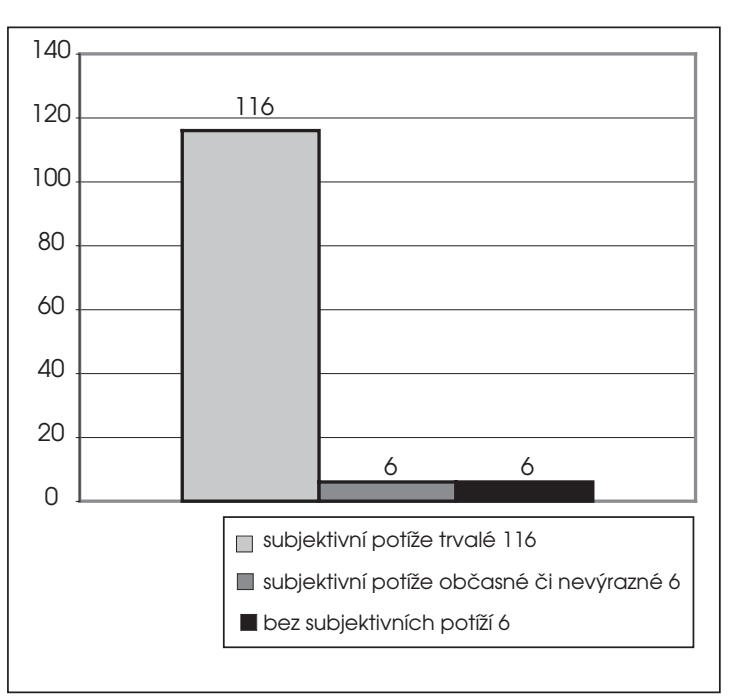

Graf 1 Subjektivní potíže

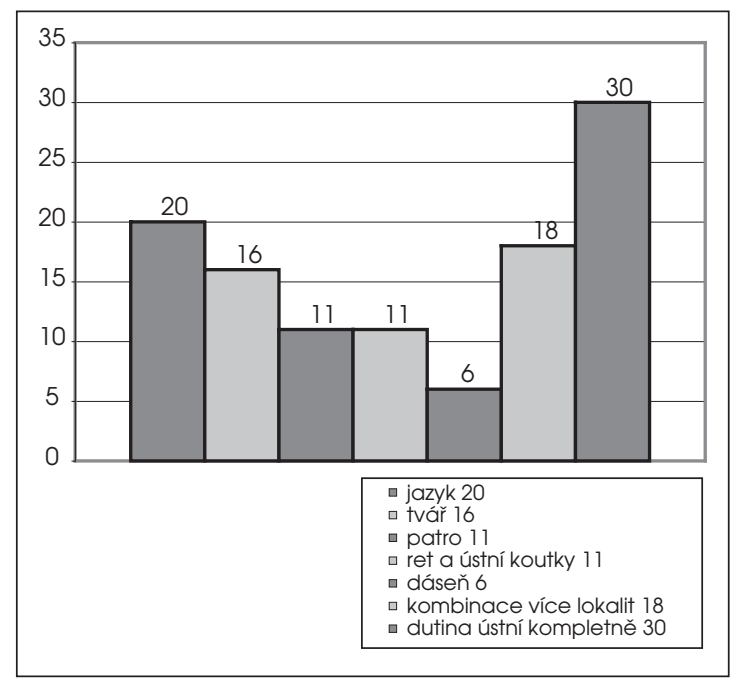

Graf 2 Lokalizace subjektivních potíží
PRAKTICKÉ

ZUBNİ

LÉKAR̆STVİ

roč. 59

2011, č. 4

s. $78-84$ 


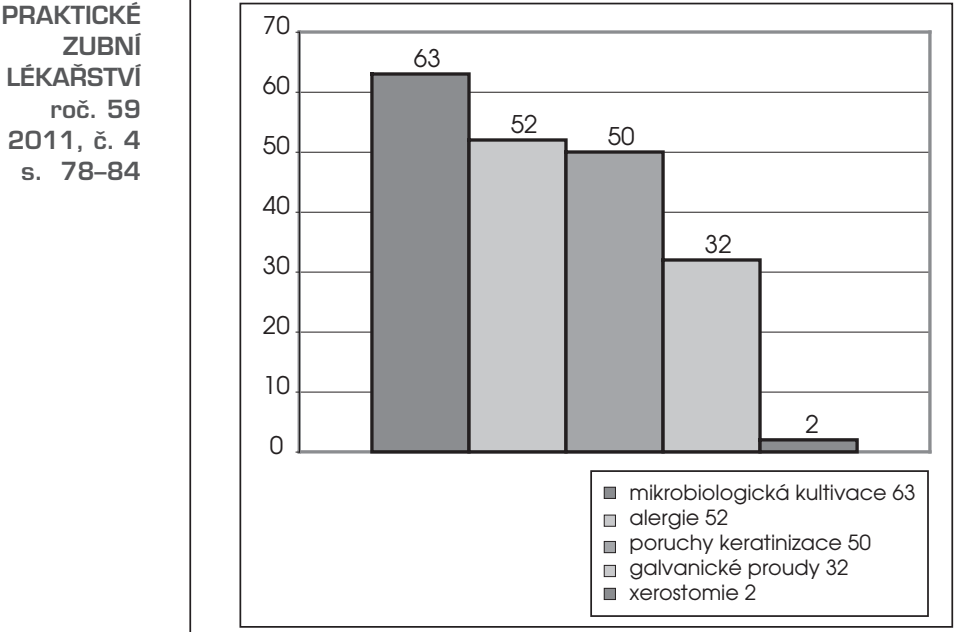

Graf 3 Výsledky jednotlivých vyšetření

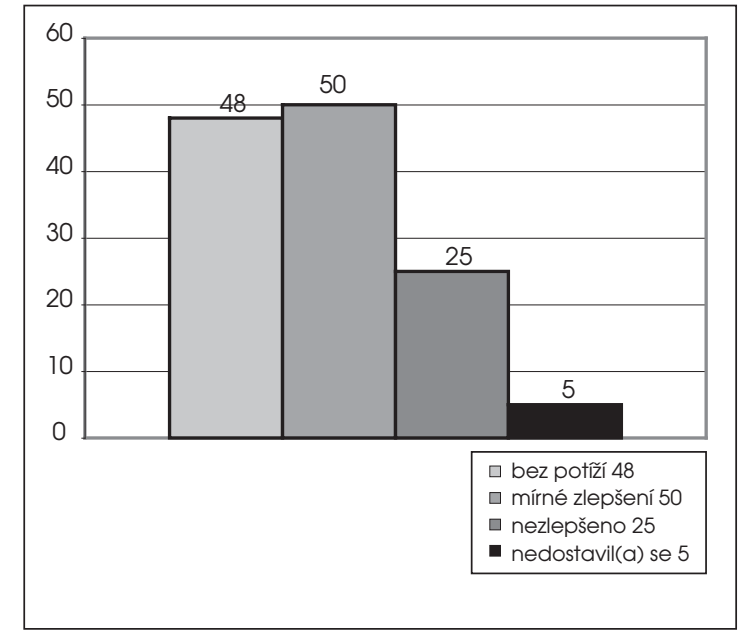

Graf 4 Výsledky po léčbě

Většina pacientů přicházela se subjektivními potížemi, které 116 pacientů klasifikovalo jako trvalé problémy, 6 dotázaných udávalo potíže občasné či nevýrazné a stejný počet pacientů neudával žádné potíže, jednalo se o náhodný nález, učiněný při preventivních prohlídkách, nebo si pacient všiml změn na sliznici ústní dutiny sám.

Graf 1 znázorňuje rozložení subjektivních potíží u sledovaného souboru. Celkem 122 pacientů z celkového počtu 128 udávalo subjektivní potíže.

K nejčastějším problémům patřilo štípání až pálení sliznice dutiny ústní (celkem 54 vyšetřených), dalším nejčastěji udávaným problémem bylo sucho v ústní dutině (26 pacientů), často $\mathrm{v}$ kombinaci s pocitem zápachu $\mathrm{z}$ úst, následují potíže vystupňované do bolestí sliznic ústní dutiny, a to u 22 pacientů. Dále 16 dotázaných uvedlo poruchy chuti a stejný počet i nejrůznější nepř́ijemné pocity (parestézie). Celkem 12 pacientů pozorovalo bílý povlak na sliznicích, v jednom případě šlo o tmavý povlak jazyka. $Z$ dalších popisovaných příznaků to byly puchýře $\mathrm{v} 10$ případech a rovněž pocit otoku, také u 10 dotázaných. Pouze 3 pacienti pozorovali zarudnutí sliznic. Ojediněle se vyskytly i celkové př́iznaky, například únava, bolesti hlavy, hučení v uších. U velké části pacientů se jednalo o kombinaci více uvedených potíží. ti.

Graf 2 znázorňuje postižení jednotlivých částí dutiny ústní tak, jak je vnímali pacien-

Výsledky jednotlivých vyšetření pak znázorňuje graf 3. Velký podíl na potížích charakteru pálivého syndromu měla dysmikrobie, za ní následuje prokázaná alergie na dentální materiály.

Výsledky po léčbě můžeme sledovat na grafu 4, který mapuje především subjektivní pocity pacienta po léčbě, která následovala po jeho kompletním vyšetření a byla vždy zaměřena na konkrétní výsledky vyšetření. Často se jednalo o terapii kombinovanou, zacílenou na jednotlivé prř́činy. Posloupnost ošetření byla vždy stanovena individuálně, dle závažnosti.

Úplné zlepšení po léčbě udávalo $37,5 \%$ pacientů, tedy 48 z celkového počtu 128 sledovaných osob. Jednalo se zejména o pacienty s dysmikrobií, s pozitivním průkazem alergie, galvanických proudů a jejich kombinace. Mírného zlepšení jsme docílili u 50 $(39,06 \%)$ pacientů. Jednalo se opět o přeléčení mikrobiální infekce, odstranění galvanických jevů a vyloučení alergického dráždění, v přibližně stejném zastoupení jako u předešlé skupiny. Úplného zlepšení nebylo dosaženo $z$ důvodu př́tomnosti objektivních změn na sliznici ústní dutiny (poruchy keratinizace) a vlivem celkového zdravotního stavu. Nelze také vyloučit u sledovaných žen postmenopauzální syndrom. Ke zlepšení nedošlo u 25 (19,53 \%) pacientů (pouze dva muži). Do této skupiny se řadí nemocní s bohatou celkovou a farmakologickou anamnézou, ve dvou případech šlo o pacienty s histologicky pozitivním nálezem na sliznici dutiny ústní - erozivní lichen, slizniční pemphigoid. Ženy, které tvořily téměř celou tuto skupinu, byly v 17 př́padech v období menopauzy a postmenopauzy. Ani zde nelze proto vyloučit hormonální změny typické pro toto období a pro vznik stomatodynií. 


\section{DISKUSE}

Bakteriální infekce dutiny ústní představuje narůstající problém v mnoha zemích. Populace stárne, přibývá pacientů s řadou celkových systémových onemocnění a pacientů s rozsáhlou a pestrou medikací, čímž se zvyšuje riziko oportunních infekcí. Klasickým představitelem je rod Candida [5]. Součástí takovýchto stavů bývá často xerostomie, at už poléková či vyvolaná zdravotním stavem pacienta. Narušená salivace se podílí na vzniku patogenních infekcí v dutině ústní, a to jak kandidóz, tak i jiných. Obecně víme, že terapie těchto stavů bývá obvykle obtížná.

Poměrně častou přičinou stomatodynie u našich pacientů byla narušená mikrobiologická rovnováha dutiny ústní. Nejčastějším původcem bývá Candida albicans, jako druhý nejčastější patogen je v literatuře označován Aspergillus spp. Aspergilózy jimi vyvolané bývají těžko léčitelné [15]. Při našich vyšetřeních jsme se s výskytem Aspergillus spp. nesetkali.

Zdrojem potíží v dutině ústní nemusí být vždy nutně patologické přemnožení orálních bakterií, ale může se jednat o osídlení či přestup infekce při chronických onemocněních z dolních cest dýchacích, při zánětu středouší či při chronických tonzilitidách. V takovýchto př́ipadech je potom veškerá lokální léčba neúspěšná a je nutná spolupráce i s jinými specialisty [4], což poukazuje na obtížnost terapie.

Kromě mykologické kultivace jsme prováděli také bakteriologické vyšetření, jehož výsledky byly velice pestré. Poměrně častým nálezem byly gramnegativní fakultativně anaerobní tyčky rodu Haemophillus. Tyto bakterie většinou nezpůsobují velké potíže pro svou nízkou patogenitu, ovšem u disponovaných jedinců mohou vyvolat zánětlivé bakteriální endokarditidy. $V$ případě přemnožení hemofilů je proto vhodné jejich přeléčení [20].

Druhou příčinou dynických potíží u našich pacientů byla alergie na dentální materiály. Nejčastěji diskutovaným alergenem je rtut, respektive soli rtuti. Z narušeného amalgámu se při broušení a vrtání uvolňuje kovová rtut do vodného a plynného prostředí, kde se oxiduje na dvojmocnou rtut, která je alergogenní a může vyvolat senzibilizaci [8]. Alergie se může projevovat nejrůznějšími parestéziemi v dutině ústní, eflorescencemi, nejčastěji lichenoidního charakteru. Lichenoidní reakce na sliznici dutiny ústní mohou být tudíž projevem kontaktní alergie, která je v dutině ústní nejčastější. Kontaktní alergie na různé kovy může hrát také úlohu v exacerbaci dosud klidného onemocnění orálního lichen planus (OLP). Nejběžnějšími alergeny jsou obecně nikl, paladium, chrom, kobalt [11]. Lichenoidní reakce se mohou objevit i po aplikaci dentálních výplní či náhrad zhotovených ze syntetických pryskyřic [7].

Vedlejší nežádoucí projevy dentálních slitin mohou být nejen alergického původu, ale také se může jednat o iritaci na podkladě toxického, mechanického či galvanického dráždění.

Zajímavé postavení v oblasti alergického dráždění mají látky (především esenciální oleje, parfémy), které se užívají jako součást topických léčivých přípravků, ústní kosmetiky, různých pochutin a nápojů, mohou být součástí fytoterapeutik, ale také dentálních materiálů. Tyto látky kromě nespecifické kontaktní stomatitidy a cheilitidy mohou být i příčinou lichenoidních projevů [7]. Jsou to preparáty, o nichž se v běžné populaci př́íliš mnoho neví, ale mohou pacientům způsobovat nemalé potíže. Lze potom stěží vyslovit diagnózu stomatodynie při setrvalých subjektivních potížích pacienta, byla-li námi prokázána alergie na některou $z$ uvedených složek.

Kromě alergií mohou dentální slitiny způsobovat i dráždění sliznic na základě galvanických proudů. Pro stanovení galvanických proudů se provádí měření napětí mezi kovem a gingivou, kovem a jazykem a kovem a kovem. Za nadprahovou hladinu je dle autorů považována hodnota vyšší než $5 \mu \mathrm{A}$ [25]. Dle našich měření a výsledků ostatních autorů lze říci, že galvanické proudy v dutině ústní mohou u citlivých pacientů vyvolávat zdravotní potíže ve smyslu dynií, ale mohou i souviset jak se vznikem patologických lézí v dutině ústní, tak mohou být i příčinou celkových zdravotních potíží. Odstranění elektro-aktivních výplní se jeví jako účinný léčebný zákrok [17, 24]. 


\section{ZÁVĚR}

Cílem práce bylo monitorování etiopatogenetických faktorů stomatodynií. Následně pak cílená a adekvátní léčba našich pacientů, zaměřená na vyvolávající příčinu, byla-li tato odhalena.

Naše studie ukazuje, že př́ičiny stomatodynií, at už v užším či širším slova smyslu, jsou rozmanité, často i obtížně identifikovatelné. Současně také dokládá, že řešení uvedených potíží je $\mathrm{v}$ některých případech možné, eventuálně je $\mathrm{v}$ našich silách alespoň částečně pacientovi ulehčit v jeho spíše psychickém strádání.

\section{LITERATURA}

1. Bains, V. K., Loomba, K., Loomba, A., Bains, R.: Mercury sensitisation: review, relevance and a clinical report. Br. Dent. J., roč. 205, 2008, č. 7, s. $373-378$.

2. Buchanan, J., Zakrzewska, J.: Burning mouth syndrome. BMJ Clinical Evidence, 2008, 03, s. $1301-1308$

3. Corazza, M., Levratti, A., Virgih, A.: Allergic contact cheilitis dus to carvone in toothpastes. Contact Dermatitis, roč. 46, 2002, s. 366-367.

4. Dahlén, G.: Non-odontogenic infections in dentistry. Periodontology 2000, roč. 49, 2009, s. 7-12.

5. Dahlén, G.: Bacterial infections of the oral mucosa. Periodontology 2000, roč. 49, 2009, s. 13-38.

6. De Rossi, S. S., Greenberg, M. S.: Intraoral contact allergy: a literature review and case reports. J. Am. Dent. Assoc., roč. 129, 1998, č. 10, s. $1435-1441$.

7. Ditrichová, D., Kaprálová, S., Tichý, M., Tichá, V., Dobešová, J., Justová, E., Eber, M., Pírek, P.: Oral lichenoid lesions and allergy to dental materials. Biomed. Pap. Med. Fac. Univ. Palacky Olomouc Czech Repub., roč. 151, 2007, č. 2, s. 333-339.

8. Dobešová, J., Ditrichová, D., Kaprálová, S., Pírek, P., Eber, M.: Kontaktní alergická cheilitida. Derma, roč. VII, 2007, č. 1, s. 12-16.

9. Fedele, S., Fricchione, G., Porter, S. R., Mignogna, M. D.: Burning mouth syndrome (stomatodynia). QJM, roč. 100,2007 , č. 8, s. 527-530.

10. Grushka, M., Epstein, J. B., Gorsky, M.: Burning mouth syndrome. Am. Fam. Physician, roč. 65, 2002, č. 4, s. 615-622.

11. Hosoki, M., Bando, E., Asaoka, K., Takeuchi, H., Nishigawa, K.: Assessment of allergic hypersenzitivity to dental materials. Biomed. Mater. Eng., roč. 19, 2009, č. 1, s. 53-61.

12. Ivančaková, R., Slezák, R.: Infekce ústní sliznice. Med. pro Praxi, 2006, č. 6, s. 288-290.

13. Jirásková, M.: Dermatovenerologie pro stomatology. 1. vyd., Praha, Professional Publishing, 2001. ISBN 80-86419-07-X.

14. Kalfus, P., Dřizhal, I., Živný, P.: Orální lichen planus a hepatitida C. LKS, roč. 16, 2006, č. 2 s. 18-21.

15. Pallasch, T. J.: Antifungal and antiviral chemotherapy. Periodontology 2000, roč. 28, 2002, s. $240-255$.

16. Pinto, A., Stoopler, E. T., DeRossi, S. S., Sollecito, T. P., Popovic, R.: Burning mouth syndrome: a guide for the general practitioner. Gen. Dent., roč. 51, 2003, č. 5, s. 458-461.

17. Poddaná, M., Joska, L., Venclíková, Z.: Vliv koroze na vznik pigmentace měkké tkáně. Čes. Stomat., roč. 107, 2007, č. 1, s. 10-13.

18. Slezák, R., Ryška, A.: Kouření a dutina ústní 1. vyd., Praha, Havlíček Brain Team, 2006. ISBN 80-903609-6-3.

19. Slezák, R.: Malé ilustrované repetitorium. LKS, roč. 16,2006 , č. 10 , s. 31-32.

20. Slezák, R.: Stručná charakteristika rezidentní mikroflóry dutiny ústní. Folia Parodontologica Bohemica, roč. 3, 2007, č. 4, s. 11-17.

21. Slezák, R., Dřízhal, I., Hubková, V., Doležalová, H., Pavlicová, A., Nováková, V., Kopecký, O.: Choroby ústní sliznice v praxi zubního lékaře. LKS, roč. 17,2007 , č. 10 , s. 26-28.

22. Stanford, T. W., Rivera-Hidalgo, F.: Oral mucosal lesions caused by infective microorganisms. II. Fungi and parasites. Periodontology 2000, roč. 21, 1999, s. 125-144.

23. Škach, M., Švejda, J., Liška, K.: Onemocnění ústní sliznice. 2. vyd., Praha, Avicenum, 1975.

24. Vavřičková, L., Dostálová, T., Vahalová, D., Šrámková, J.: Koroze dentálních slitin. Prakt. zub. Lék., roč. 55, 2007, č. 5, s. 87-93.

25. Vavřičková, L., Dostálová, T., Vahalová, D.: Dentální slitiny kovů. Část I.: Dělení dentálních slitin, fyzikální a chemické vlastnosti. Čes. Stomat., roč. 108, 2008, č. 2, s. 39-46.

26. www:dentalgentlecare.com/burning_mouth_syndrome.htm.

27. www.mayoclinic.com/health/burning-mouthsyndrome/DS00462.

28. www.nidcr.nih.gov/OralHealth/Topics/Burning/BurningMouthSyndrome.htm.

Řešeno s podporou grantu IGA MZ ČR NR 8379-3.

MUDr. Simona Kaprálová Klinika zubního lékařství LF UP a FN

Palackého 12

779 oo Olomouc e-mail: kapralova.simona@centrum.cz 